\title{
Economic Evaluation of CCUS Retrofitting of Coal-fired Power Plants Based on Net Cash Flow
}

\author{
Jingqi Jin ${ }^{1}$, Feng Xue ${ }^{1}$, Bin Cai ${ }^{1,}{ }^{*}$, Xinxin Yang ${ }^{2}$, Yening Lai ${ }^{1}$, Dalin $\mathrm{Jiang}^{3}$, Yalin $\mathrm{Mao}^{3}$, and Yi $\mathrm{Tao}^{3}$ \\ ${ }^{1}$ NARI Group Corporation/State Grid Electric Power Research Institute, Nanjing 211106, PR China \\ ${ }^{2}$ School of Electrical Engineering, Southeast University, 2 Sipailou, Nanjing 210096, PR China \\ ${ }^{3}$ Shenhua Science and Technology Research Institute Co.,Ltd.,201 Shenhua S\&T Innovation Base, Beijing 102211, PR China
}

\begin{abstract}
Carbon Capture, Utilization and Storage (CCUS) is one of the key technologies for realizing largescale low-carbon utilization of coal-fired power plants in service. How to evaluate its economics is crucial to the decision-making of traditional coal-fired power enterprises. This paper analyzes the changes in the physical, emission and economic parameters of in-service coal-fired power plants without and with the CCUS retrofit. A method for evaluating the economic feasibility of coal-fired power plants retrofitting based on net cash flow is proposed, which compares the impact of CCUS retrofit on the net present value of the remaining life cycle of the power plant. The impact of uncertain parameters such as carbon dioxide sales unit price, carbon capture device operating cost, free carbon quota, and carbon emission right price on the evaluation results are analyzed.
\end{abstract}

\section{Introduction}

The clean and low-carbon transition has become a global consensus, but large-scale coal-fired power will still occupy an important position in the power production structure for a period of time in the future ${ }^{[1-2]}$. After coalfired power has achieved ultra-low emission of pollutants, carbon emissions have become the primary issue affecting the sustainable development of coal-fired power enterprises $^{[3]}$.

Carbon Capture, Utilization and Storage (CCUS) refers to an industrial process that separates carbon dioxide $\left(\mathrm{CO}_{2}\right)$ from industrial emission sources or directly uses or stores it to achieve $\mathrm{CO}_{2}$ emission reduction ${ }^{[4]}$. The International Energy Agency points out that CCUS is the only way to significantly reduce $\mathrm{CO}_{2}$ emissions from fossil fuels ${ }^{[5]}$. The Intergovernmental Panel on Climate Change also emphasizes that CCUS technology is an important lifeline to combat climate change, and it will be difficult to achieve emission reduction targets without CCUS $^{[6-7]}$. According to the energy revolution roadmap of The National Development and Reform Commission/ National Energy Administration, China is expected to realize the commercial application of CCUS in $2030^{[8]}$. The literature [4] has formulated China's CCUS technology development roadmap. It is believed that the cost of CCUS is expected to drop rapidly, and the application scale of CCUS is expected to reach 1-3 billion tons/year by 2050 .

Allowing investors to obtain positive economic returns is the key to the large-scale commercial application of CCUS technology. Existing research generally uses real option method and net present value method to evaluate CCUS investment. The literature [9] evaluates the cost of electricity loss caused by CCS retrofit through the net profit per unit power generation of coal-fired power plants given exogenously. The literature [10] regards the investment cost of CCS project as the only cost of CCS retrofit, but none of the above studies has conducted a detailed analysis of the cash inflow and outflow of the entire coal-fired power plant after CCS retrofit. The literature [11] carries out an economic evaluation on the complete process of CCS after combustion, and analyzes the cost and benefit of CCS technology in detail, but does not analyze coal-fired power plants and CCS technology as a whole. In view of the shortcomings of the above research, this paper analyzes the coal-fired power plant and CCUS retrofit as a whole, and calculates its net cash flow year by year during the remaining life cycle.

The remainder of the paper is structured as follows: section 2 introduces the evaluation method. Section 3 is the case study, which introduces the baseline scenario and uncertain parameters. Section 4 is the result analysis, which analyzes the research results under the baseline scenario and the sensitivity of uncertain parameters. The last section is the conclusion.

\section{Methodology}

\subsection{Evaluation method}

The basic idea of this assessment method is: first, calculate the net cash flow of the retrofit without CCUS and retrofit with CCUS during the remaining life cycle

\footnotetext{
* Corresponding author: caibin@sgepri.sgcc.com.cn
} 
from the current moment to decommissioning for the inservice coal-fired power plant to be assessed; then, compare the net present value difference after discounting to the current year at a certain discount rate; finally, the economic feasibility of CCUS retrofit for coal-fired power plants is evaluated through the change of the net present value difference.

\subsection{Calculation method}

Net cash flow refers to the difference between cash inflow and cash outflow in a certain period. In this study, the year is taken as the calculation step. The current year is recorded as $t_{0}$, the year when the coal-fired power plant is decommissioned is recorded as $t_{f}$, and the year when CCUS retrofit is implemented is recorded as $t_{r}$, where $t_{0}$ $\leqslant t_{r} \leqslant t_{f}$. The calculation is divided into the following three parts.

(1) The net cash flow of the coal-fired power plant in each period without the retrofit can be expressed as:

$$
\begin{gathered}
\mathrm{NCF}_{i}=C_{i}^{\text {in }}-C_{i}^{\text {out }} \\
C_{i}^{\text {in }}=R_{i}^{\text {pgs }}+R_{i}^{\text {VATs }}+R_{i}^{\text {rvfa }} \\
C_{i}^{\text {out }}=C_{i}^{\text {ce }}+C_{i}^{\text {rlp }}+C_{i}^{\text {rli }}+C_{i}^{o}+C_{i}^{\text {pcVAT }}+C_{i}^{\text {st }}+C_{i}^{\text {pit }}+C_{i}^{\text {moi }}
\end{gathered}
$$

Where $\mathrm{NCF}_{i}$ represents net cash flow, $C_{i}^{\text {in }}$ represents cash inflow, $C_{i}^{\text {out }}$ represents cash outflow, $R_{i}^{\text {pgs }}$ represents power generation sales revenue, $R_{i}^{\text {VATS }}$ represents VAT subsidy income, $R_{i}^{r v f a}$ represents recovery of residual value of fixed assets, $C_{i}^{c e}$ represents capital expenditure, $C_{i}^{r l p}$ represents repayment of loan principal, $C_{i}^{r l i}$ represents repayment of loan interest, $C_{i}^{o}$ represents operating costs, $C_{i}^{\text {pcVAT }}$ represents pay current VAT, $C_{i}^{\text {st }}$ represents sales tax and surcharges, $C_{i}^{\text {pit }}$ represents pay income tax, $C_{i}^{\text {moi }}$ represents maintain operating investment.

(2) The net cash flow of the coal-fired power plant in each period with the retrofit can be expressed as:

In the time range $t_{r}$ to $t_{f}$, the net cash flow $N C F_{i}^{\text {ccus }}$ of the target coal-fired power plant in service should be calculated after the CCUS retrofit for each time period. CCUS and coal-fired power plants are decommissioned together, and CCUS has completed repayment and depreciation before decommissioning. Update related technical and economic parameters for the coal-fired power plant after CCUS retrofit.

$$
\begin{aligned}
& N C F_{i}^{\text {ccus }}=C_{i}^{\text {in,ccus }}-C_{i}^{\text {out }, \text { ccus }} \\
& \begin{aligned}
& C_{i}^{i n, c c u s}=R_{i}^{\text {pgs,ccus }}+R_{i}^{\text {si }}+R_{i}^{\text {rvfa,ccus }}+R_{i}^{\text {cds }} \\
C_{i}^{\text {out }, \text { ccus }}= & C_{i}^{\text {ce,ccus }}+C_{i}^{\text {rlp,ccus }}+C_{i}^{\text {rli,ccus }}+C_{i}^{o, c c u s}+C_{i}^{p \text { cVAT, ccus }} \\
& +C_{i}^{\text {st, ccus }}+C_{i}^{\text {pit,ccus }}+C_{i}^{\text {moi, ccus }}+C_{i}^{\text {cdt }}+C_{i}^{r}
\end{aligned}
\end{aligned}
$$

Where $N C F_{i}^{\text {ccus }}$ represents net cash flow with CCUS retrofit, $C_{i}^{\text {in,ccus }}$ represents cash inflow with CCUS retrofit, $C_{i}^{\text {out,ccus }}$ represents cash outflow with CCUS retrofit, $R_{i}^{\text {pgs,ccus }}$ represents power generation sales revenue with CCUS retrofit, $R_{i}^{s i}$ represents the total subsidy income with CCUS retrofit, $R_{i}^{r v f a, c c u s}$ represents recovery of residual value of fixed assets with CCUS retrofit, $R_{i}^{\text {cds }}$ represents carbon dioxide sales revenue with CCUS retrofit, $C_{i}^{c e, c c u s}$ represents capital expenditure with CCUS retrofit, $C_{i}^{r l p, c c u s}$ represents repayment of loan principal with CCUS retrofit, $C_{i}^{r l i, c c u s}$ represents repayment of loan interest with CCUS retrofit, $C_{i}^{o, c c u s}$ represents operating costs with CCUS retrofit, $C_{i}^{\text {pcVAT,ccus }}$ represents pay current VAT with CCUS retrofit, $C_{i}^{\text {st,ccus }}$ represents sales tax and surcharges with CCUS retrofit, $C_{i}^{\text {pit,ccus }}$ represents pay income tax with
CCUS retrofit, $C_{i}^{\text {moi,ccus }}$ represents maintain operating investment with CCUS retrofit, $C_{i}^{\text {cdt }}$ represents carbon dioxide transportation cost with CCUS retrofit, $C_{i}^{r}$ represents running cost with CCUS retrofit.

(3) The net present value of the coal-fired power plant without and with retrofit can be expressed as:

$$
\begin{aligned}
N P V_{\text {without } C \text { CUS }} & =\sum_{\substack{i=t_{r} \\
t_{f}}}^{t_{f}} \frac{N C F_{i}}{(1+r)^{t_{r}-i}} \\
\mathrm{NPV} V_{\text {with } \text { CCUS }} & =\sum_{i=t_{r}} \frac{N C F_{i}^{c c u s}}{(1+r)^{t_{r}-i}}
\end{aligned}
$$

Where $N P V_{\text {without ccus }}$ represents net present value without CCUS retrofit, $\mathrm{NP} V_{\text {with ccus }}$ represents net present value with CCUS retrofit, $r$ represents discount rate.

Calculate and discount the net cash flow without and with the CCUS retrofit to the current year's net present value at a certain discount rate, and compare the changes in the net present value without and with the CCUS technology retrofit in the remaining life cycle. If $N P V_{\text {with CCUS }}-N P V_{\text {without CCUS }}>0$ and $N P V_{\text {with CCUS }}>0$, then it is judged that CCUS retrofit is worth investing in; if $N P V_{\text {with CCUS }}-N P V_{\text {without } C C U S}=0$, then it is expressed as a critical state; if $N P V_{\text {with } C C U S}-N P V_{\text {without } C C U S}<0$, then it is judged that CCUS retrofit is not worth investing in.

\section{Case study}

\subsection{Baseline scenario parameters setting}

This paper takes an in-service coal-fired power plant as an example for analysis. The parameters of the baseline scenario are set as follows:

(1) Time parameters

The coal-fired power plant has put a thermal power unit into operation in 2010 and it will be decommissioned at the end of 2044. The current year is 2019. The design depreciation period is 20 years and the repayment period is 15 years.

(2) Physical parameters

The installed capacity is $600 \mathrm{MW}$, the annual power utilization hours are 4000 hours, and the auxiliary power rate is $5 \%$.

(3) Emission parameters

Carbon emission right price is 40 yuan/ton, and it will increase at a rate of 1 yuan/ton per year; the proportion of free carbon quota in 2019 is $100 \%$, which will be reduced by $1 \%$ per year.

(4) Economic parameters

The coal price is 500 yuan/ton of standard coal, and the benchmark loan interest rate is $4.9 \%$.

The specific data are shown in Table 1.

The parameters for the CCUS retrofit of in-service coal-fired power plant are as follows:

(1) Time parameters

The coal-fired power plant will complete the CCUS retrofit in 2030 and it will be decommissioned together with the thermal power unit at the end of 2044. The design depreciation period of CCUS equipment is 10 years, and the repayment period is 10 years.

(2) Physical parameters 
The annual carbon dioxide capture capacity of the CCUS device is 300,000 tons. The additional coal consumption due to the operation of the CCUS device is 0.1 ton of standard coal/ton carbon dioxide.

(3) Economic parameters

The cost of CCUS is 500 yuan per ton of carbon dioxide. The annual operating cost is 188 yuan/ton carbon dioxide. All the captured $\mathrm{CO}_{2}$ is transported and sold at a unit price of 450 yuan/ton carbon dioxide.

The specific data are shown in Table 2.

Table 1. Parameters table of coal-fired power plant under the baseline scenario.

\begin{tabular}{|c|c|c|}
\hline Parameters & Value & Unit \\
\hline Installed capacity & 600 & Megawatt \\
\hline Annual power utilization hours & 4000 & Hours \\
\hline Auxiliary power rate & 5 & $\%$ \\
\hline $\begin{array}{l}\text { Coal consumption per unit of } \\
\text { power supply (standard coal) }\end{array}$ & 330 & $\mathrm{~g} / \mathrm{kwh}$ \\
\hline $\begin{array}{c}\text { Coal price } \\
\text { (tax included) }\end{array}$ & 500 & Yuan/tce \\
\hline Value-added tax rate & 13 & $\%$ \\
\hline Carbon emission right price & 40 & $\begin{array}{c}\text { Yuan/ton } \\
\text { carbon dioxide }\end{array}$ \\
\hline Proportion of free carbon quota & 100 & $\%$ \\
\hline $\begin{array}{l}\text { On-grid electricity price (tax } \\
\text { included) }\end{array}$ & 0.391 & Yuan/kwh \\
\hline Discount rate & 5 & $\%$ \\
\hline Comprehensive tax rate & 12 & $\%$ \\
\hline $\begin{array}{l}\text { Operation and maintenance } \\
\text { cost }\end{array}$ & 48 & Yuan/MWh \\
\hline Manufacturing cost & 3390 & Yuan/kw \\
\hline Total investment & 2034 & Million yuan \\
\hline Capital & 406.8 & Million yuan \\
\hline Capital ratio & 20 & $\%$ \\
\hline Residual value & 91.53 & Million yuan \\
\hline
\end{tabular}

Table 2. CCUS parameters table under the baseline scenario.

\begin{tabular}{|c|c|c|}
\hline Parameters & Value & Unit \\
\hline $\begin{array}{c}\text { Annual carbon } \\
\text { dioxide capture }\end{array}$ & 30 & Ten thousand tons \\
\hline $\begin{array}{c}\text { Coal consumption due } \\
\text { to wastage }\end{array}$ & 0.1 & Tce/ton carbon dioxide \\
\hline $\begin{array}{c}\mathrm{CO}_{2} \text { sales unit price } \\
\text { (tax included) }\end{array}$ & 450 & $\begin{array}{c}\text { Yuan/ton carbon } \\
\text { dioxide }\end{array}$ \\
\hline
\end{tabular}

\begin{tabular}{|c|c|c|}
\hline $\begin{array}{c}\mathrm{CO}_{2} \text { transportation } \\
\text { unit price } \\
\text { (tax included) }\end{array}$ & 50 & $\begin{array}{c}\text { Yuan/ton carbon } \\
\text { dioxide }\end{array}$ \\
\hline $\begin{array}{c}\text { Carbon capture device } \\
\text { operating cost }\end{array}$ & 188 & $\begin{array}{c}\text { Yuan/ton carbon } \\
\text { dioxide }\end{array}$ \\
\hline Manufacturing cost & 500 & $\begin{array}{c}\text { Yuan/ton carbon } \\
\text { dioxide } \text { year }\end{array}$ \\
\hline Total investment & 150 & Million yuan \\
\hline Capital & 30 & Million yuan \\
\hline Loan & 120 & Million yuan \\
\hline Residual value & 6.75 & Million yuan \\
\hline
\end{tabular}

\subsection{Uncertain parameters}

A large number of uncertain parameters are involved in the evaluation of CCUS retrofit of coal-fired power plants. The uncertain parameters that affect the economic feasibility of the retrofit can be divided into: the parameters that only affect the net present value with the CCUS retrofit and the parameters that both affect the net present value without and with the CCUS retrofit. The former mainly includes the parameters related to CCUS, such as $\mathrm{CO}_{2}$ sales unit price, $\mathrm{CO}_{2}$ transportation unit price, carbon capture device cost and carbon capture device operating cost, etc.; the latter mainly includes carbon emission right price, free carbon quota, coal price, and annual power utilization hours.

The key uncertain parameters analyzed in this study are shown in Table 3.

Table 3. Uncertain parameters table.

\begin{tabular}{|c|c|c|c|}
\hline Parameters & Value & Unit & $\begin{array}{c}\text { Variation } \\
\text { range }\end{array}$ \\
\hline $\begin{array}{c}\mathrm{CO}_{2} \text { sales unit } \\
\text { price } \\
\text { (tax included) }\end{array}$ & 450 & $\begin{array}{c}\text { Yuan/ton } \\
\text { carbon dioxide }\end{array}$ & $50-700$ \\
\hline $\begin{array}{c}\mathrm{CO}_{2} \\
\text { transportation } \\
\text { unit price } \\
\text { (tax included) }\end{array}$ & 50 & $\begin{array}{c}\text { Yuan/ton } \\
\text { carbon dioxide }\end{array}$ & - \\
\hline $\begin{array}{c}\text { Carbon } \\
\text { capture device } \\
\text { cost }\end{array}$ & 500 & $\begin{array}{c}\text { Yuan/ton } \\
\text { carbon } \\
\text { dioxide·year }\end{array}$ & - \\
\hline $\begin{array}{c}\text { Carbon } \\
\text { capture device } \\
\text { operating cost }\end{array}$ & 188 & $\begin{array}{c}\text { Yuan/ton } \\
\text { carbon dioxide }\end{array}$ & $50-400$ \\
\hline $\begin{array}{c}\text { Annual } \\
\text { increase in } \\
\text { carbon } \\
\text { emission right } \\
\text { price }\end{array}$ & 1 & $\begin{array}{c}\text { Yuan/ton } \\
\text { carbon dioxide }\end{array}$ & $1-10$ \\
\hline $\begin{array}{c}\text { Annual } \\
\text { reduction rate } \\
\text { of free carbon } \\
\text { quota }\end{array}$ & 1 & 500 & - \\
\hline $\begin{array}{c}\text { Coal price } \\
\text { tax included) }\end{array}$ & Yuan/tce & \\
\hline
\end{tabular}




\section{Results}

\subsection{Results analysis of the baseline scenario}

Figure 1 shows the estimated annual net cash flow of coalfired power plants from 2019 to 2044 under the baseline scenario. The orange and blue curves represent the situation without and with CCUS retrofit respectively. The net present value of the coal-fired power plant has increased from 1.55 billion yuan when the CCUS retrofit is not carried out to 1.72 billion yuan when the retrofit is carried out. Therefore, it is economically feasible to carry out CCUS retrofit in 2030.

Compared with no CCUS retrofit, both the cash inflow and cash outflow of coal-fired power plant have changed with CCUS retrofit. Among them, the sales income of the captured carbon dioxide increased the cash inflow, and the investment and operation of the carbon capture device (including the increase of coal consumption) and carbon dioxide transportation cost increased the cash outflow (see Figure 2). During the remaining life cycle of the coalfired power plant, the discounted value of cash inflows increased by 866.24 million yuan, and the discounted value of cash outflows increased by 690.29 million yuan. Among them, the largest proportion of the increase in cash outflow is operating costs, which is 4.5406 million yuan $(66 \%)$, and the total value-added tax and income tax paid increased by 134.78 million yuan (20\%), and the principal and interest of CCUS loans is 73.3 million yuan (11\%), which added a total of 436.8 million yuan in net cash flow.

It should be pointed out that the impact of CCUS retrofit on cash inflows and outflows in different years is different. For example, in 2029, the net cash flow decreased by 30 million yuan due to a one-time expenditure of capital for the construction of carbon capture device but no new income; in 2030, the cash inflow from the sale of carbon dioxide was increased by 135 million yuan, but additional cash outflows such as operating costs ( 73 million yuan), principal and interest repayment (18 million yuan), and taxes (20 million yuan) were added at the same time, and net cash flow increased by 23.70 million yuan.

The two curves in Figure 1 fluctuate to varying degrees in some years. Coal-fired power plants have completed repayment, coal-fired power plants have completed depreciation of fixed assets, CCUS investment deductible value-added input tax has been deducted, and CCUS installations have completed depreciation and repayment, payments and the residual value of fixed assets recovered when power plants and carbon capture devices are decommissioned are the reasons for the changes in net cash flow in 2025, 2030, 2034, 2040 and 2044, respectively.

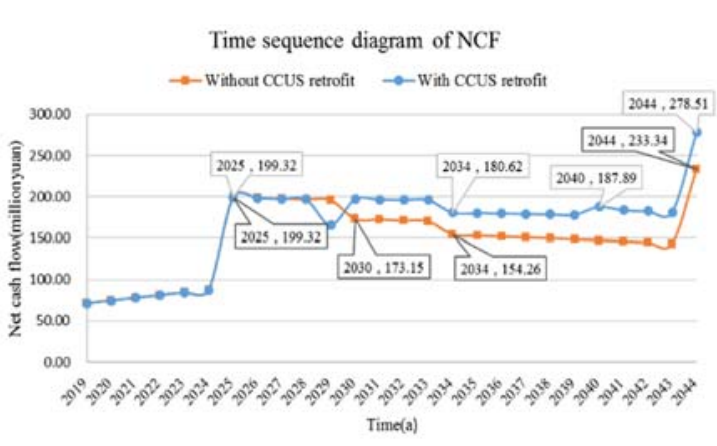

Fig. 1. Time sequence diagram of NCF with or without CCUS retrofit.

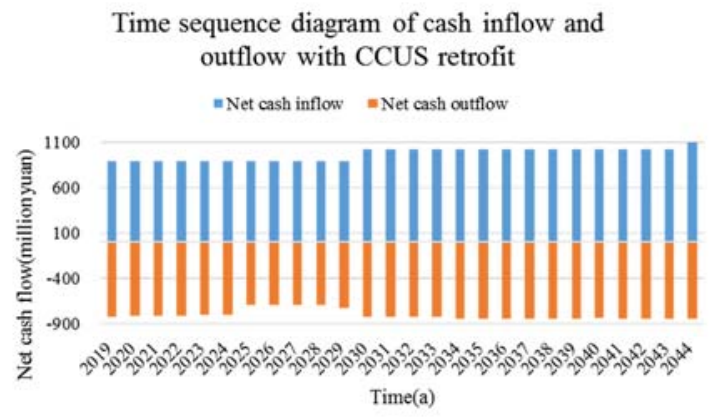

Fig. 2. Time sequence diagram of cash inflow and outflow with CCUS retrofit.

\subsection{Sensitivity analysis of uncertain parameters}

(1) Parameters that only affect CCUS retrofit

In the case of CCUS retrofit, the sales revenue of carbon dioxide is the new revenue of coal-fired power plants. The higher the sales unit price, the more conducive to the economics of CCUS retrofit (see Figure 3). In the process of increasing carbon dioxide unit price from 50 yuan/ton carbon dioxide to 700 yuan/ton carbon dioxide, the change in net present value brought about by the capture and sale of carbon dioxide in coal-fired power plants increased from -0.33 billion yuan to 0.48 billion yuan. For each increase of 10 yuan/ton, the difference of net present value increases by 0.012 billion yuan, and unit price of 300 yuan/ton of carbon dioxide is the critical point for CCUS retrofit to be economical.

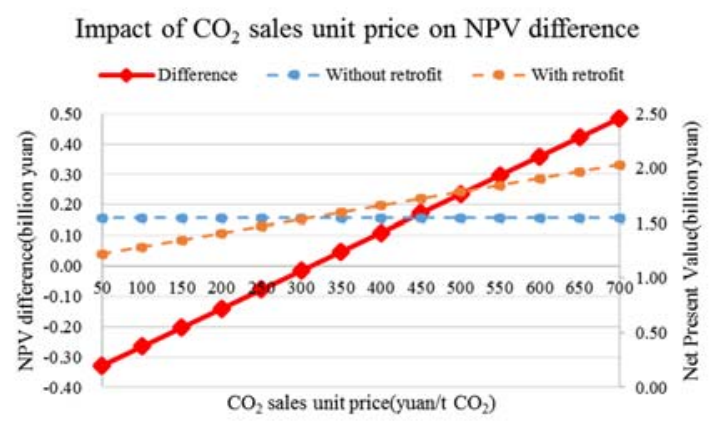

Fig. 3. Impact of $\mathrm{CO}_{2}$ sales unit price on NPV difference.

The higher the operating cost of the carbon capture device, the more unfavorable the economics of CCUS retrofit (see Figure 4). Carbon capture device operating 
cost decreased from 400 yuan/ton carbon dioxide to 50 yuan/ton carbon dioxide, and the net present value of coalfired power plant increased from -0.13 billion yuan to 0.37 billion yuan. The difference of the net present value increased by 0.07 billion yuan for each decrease of 50 yuan/ton. The operating cost of the carbon capture device is 307 yuan per ton of carbon dioxide, which is the critical point for CCUS retrofit to be economical.

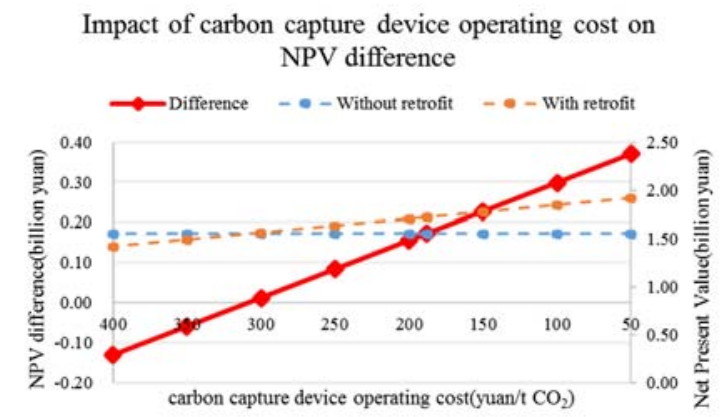

Fig. 4. Impact of carbon capture device operating cost on NPV difference.

(2) Parameters that affect situation with and without CCUS retrofit

In the process of the annual increase in carbon emission right price from 1 yuan per ton of carbon dioxide to 10 yuan per ton of carbon dioxide, the change in net present value caused by the capture and sale of carbon dioxide by coal-fired power plants increased from 0.17 billion yuan to 0.39 billion yuan (See Figure 5). The increase of carbon emission right price will increase the carbon emission cost of the coal-fired power plant. In other words, more carbon emission costs can be saved by capturing carbon dioxide. Therefore, the higher carbon emission right price, the more conducive to the economy of CCUS retrofit.

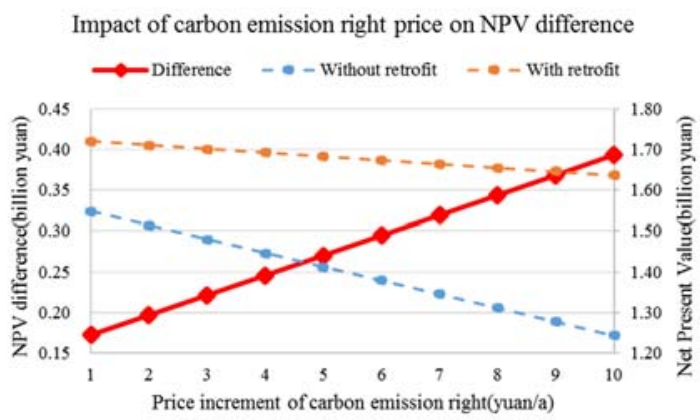

Fig. 5. Impact of carbon emission right price on NPV difference.

It is generally believed that the less the proportion of free carbon quota, the better the economics of CCUS retrofit of coal-fired power plants. However, in fact, changes in the proportion of free carbon quota will not affect the changes in the net present value of carbon dioxide captured and sold by coal-fired power plants. In the case of coal-fired power plants with and without CCUS, the reduction in the proportion of free carbon quota will reduce the net cash flow of coal-fired power plants. However, the net present value difference remains unchanged since the reduction is the same. In this example, the annual reduction rate of free carbon quota increased from $1 \%$ to $5 \%$, the net present value of coal-fired power plants dropped from 1.55 billion yuan to 1.11 billion yuan without CCUS. And the net present value dropped from 1.72 billion yuan to 1.28 billion yuan with CCUS, and the difference between the two remained at 0.17 billion yuan (see Figure 6).

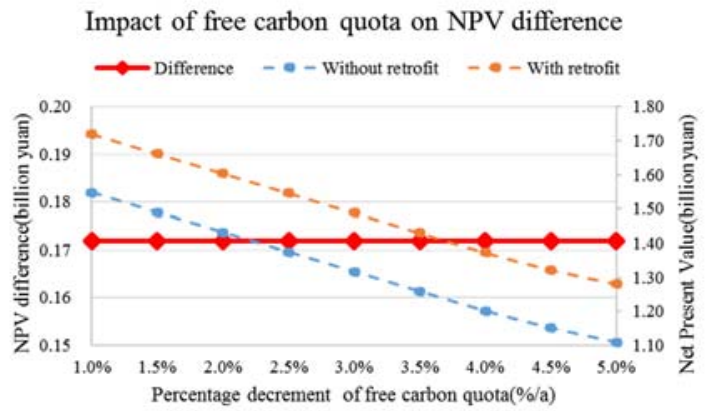

Fig. 6. Impact of free carbon quota on NPV difference.

\section{Conclusion}

Coal-fired power plants are the most important potential application targets of CCUS. Whether the income of coalfired power plants can be improved is the key to the commercial application of CCUS. This paper proposes a quantitative economic evaluation method based on the net cash flow of the CCUS retrofit by coal-fired power plants. The feasibility of the retrofitting is evaluated by comparing the difference in the net present value of the remaining life cycle of the coal-fired power plant with or without CCUS retrofit. For a typical coal-fired power plant, the impact of uncertain parameters such as the carbon dioxide sales unit price, the carbon capture device operating cost, the amount of free carbon quota, and the carbon emission right price are analyzed. Among them, the proportion of free carbon quota under the carbon market mechanism does not affect the economy and enthusiasm of CCUS retrofit of coal-fired power plants is an important discovery of this paper. This method can provide decision support for the CCUS retrofit of coalfired power plants, and it can also lay a foundation for how to coordinate and optimize the CCUS retrofit of coalfired power plants and new energy investment during the low-carbon transition process of power generation enterprises.

\section{Acknowledgments}

This work is supported by the pilot programs for major science, technology and innovation projects toward 2030 of China Energy Investment Corporation- Clean and efficient utilization of coal: Research on medium and long-term carbon emission reduction paths and energy structure optimization strategies of China(Grant No. GJNY2030XDXM-19-20.1), and the Science and Technology Project of NARI Technology Co., Ltd "Research on Key Technologies for Simulation and Evaluation of Comprehensive Energy Systems". 


\section{References}

1. J Yuan, K Zhang, Research and future forecast of coal power transformation in the middle and late period of the 13th five-year plan, China Coal, J. E 08, 13-19 (2019)(in Chinese)

2. L Liang, J Sun, M Yue, H Geng, Comparative analysis of global energy consumption mix in recent ten years. Cnpc. J. E 03, 41-47 (2020)(in Chinese)

3. J Kang, Y Wang, J Li, W Zhang, Current Situation, Trend and Orientation Analysis of Coal Power Development in China, Engry of China, J. E 08, 9-13 (2019)(in Chinese)

4. China's carbon capture, utilization and storage technology development roadmap 2019 (2019)(in Chinese)

5. International Energy Agency. The role of CCUS in low-carbon power systems, EB/OL https://webstore.iea.org/download/direct/4028?fileN ame=The_role_of_CCUS_in_lowcarbon_power_systems.pdf. $(\overline{2} 020)$

6. Intergovernmental Panel on Climate Change. Global warming of $\quad 1.5^{\circ} \mathrm{C}, \quad \mathrm{EB} / \mathrm{OL}$ https://www.ipcc.ch/site/assets/uploads/sites/2/2019/ 06/SR15_Full_Report_High_Res.pdf.(2019)

7. Intergovernmental Panel on Climate Change. Carbon Dioxide Capture and Storage, EB/OL https://www.ipcc.ch/site/assets/uploads/2018/03/srcc s_wholereport-1.pdf.(2018)

8. Energy production and consumption revolution strategy (2016-2030)(2016) (in Chinese)

9. X Zhang, M Xu, J Fan, Evaluation of incentive measures for carbon capture and storage technology transformation investment in coal-fired power plants, China Coal, J. E 12, 22-26 (2017)(in Chinese)

10. Z Lin, S Wen, B Song, Research on the Effect of Carbon Tax Policy on CCS Projects Investment Decision Based on Real Option, China Population, Resources and Environment, J. E 09, 1320 (2015) (in Chinese)

11. Z Xu, Study on Economic Assessment of a Full-Chain CCS-EOR Project based on $\mathrm{CO}_{2}$ Post-Combustion Capture of Coal-Fired Power Generation, Journal of Cleaner Production, (2016) (in Chinese) 